\title{
O Papilomavírus Humano: um fator relacionado com a formação deneoplasias
}

The Human papillomavirus: a factor related with the formation of neoplasias

Rafael Souto ${ }^{1}$ M.Sc, , Júlio Pedro Borgo Falhari ${ }^{1}$ B.Sc, Aparecido Divino da Cruz ${ }^{1,2,3}$ Ph.D.

\begin{abstract}
Resumo
O s estudos realizados nos últimos anos, com o auxílio de novas tecnologias de detecção viral, permitem-nos considerar o Papilomavírus H umano (H PV) como o agente causal do câncer do colo de útero. Além da interação com as regiões genitais, outros sítios anatômicos têm sido acometidos pelo H PV, tendo destaque as regiões da cabeça e pescoço. Esse vírus infecta tanto as mucosas quanto os tecidos cutâneos, podendo ser classificado segundo seu tropismo como mucosotrópicos ou cutaneotrópicos. Q uanto à sua capacidade de causar lesões malignas ou benignas, pode ser dividido em HPV de alto e baixo risco oncogênico. 0 potencial carcinogênico do H PV é relacionado a duas proteínas virais, E6 e E 7, as quais são capazes de interagir com proténas que regulam o ciclo celular e que atuam como supressoras de tumores, como a p53 e pRb. Essa interação provoca a degradação e inativação das proteínas celulares, o que conduziria a transformação, imortalização celular, e posteriormente, a formação de neoplasias.
\end{abstract}

Palavras-chave: Papilomavírus humano; O ncogenes; Supressores de tumor; N eoplasias.

\begin{abstract}
Recent studies using new technologies on viral detection, allow us to consider the human papillomavirus (H PV) as the etiological agent of the cervix cancer. Besides its action on genital regions, other anatomic sites have been infected by the H PV, mainly the head and neck regions. This virus infects both the mucosal and the cutaneous tissue, and can be also classified according to its tropism as mucosotropic or cutaneotropic. However, according to its capacity of causing malignant or benign lesions, it can be divided into high and low-risk oncogenic H PV. The H PV oncogenic potencial is related to two viral proteins, E6 and E7, which are capable to interact with proteins that regulate the cell cicle and act as tumor suppressors, like p53 and pRB. This interaction provokes the degradation and inactivation of the celular proteins, leading to cellular transformation, immortalization and, later, to the formation of neoplasias.
\end{abstract}

Key words Human papillomavirus; O ncogenes; Tumor suppressors; N eoplasms.

\footnotetext{
${ }^{1} \mathrm{~N}$ úcleo de Pesquisas Replicon, D epartamento de Biologia, Universidade C atólica de G oiás, Goiânia,Go .

2 Registro de Câncer de Base Populacional, Associação de Combate ao Câncer em Goiás, G oiânia, GO .

${ }^{3}$ LaG ene - Laboratório de Citogenética H umana e Genética M olecular, SuLeide/SES-GO, G oiânia, GO .

Endereço para correspondência: Rafael Souto. E-mail: rsouto@ucg.br
} 


\section{INTRO DUÇÃO}

A carcinogênese é um processso de múltiplas etapas que envolve tanto mudanças genéticas quanto epigenéticas, culminando na ativação de proto-oncogenes e/ou inativação dos genes supressores de tumor. ${ }^{1} \mathrm{~A}$ passagem da célula pelas diversas fases do ciclo celular é realizada de forma rígida por genes controladores do ciclo. U ma célula maligna difere de uma célula normal principalmente pela sua independência desse controle, sendo necessário um acúmulo de mutações nos cromossomos para tal transformação. ${ }^{2}$

Alguns tipos de Papilomavírus H umano (H PV), nos últimos anos, têm sido responsabilizados pelo desenvolvimento de malignidade nas regiões que comumente infectam, compreendendo, na mulher, 0 períneo, vulva, vagina, colo do útero e região anal; no homem, infectam pênis, uretra, saco escrotal e região anal. ${ }^{3,4}$ Além das áreas comumente descritas na literatura, o desenvolvimento de pesquisas vem demonstrando a presença de H PV de alto risco oncogênico esua possível associação com o desenvolvimento de malignidade na região de orofaringe e cordas vocais. ${ }^{5}$

Estudos recentes, usando testes meticulosos pela técnica de reação em cadeia da polimerase (PCR) de uma grande coleção de espécimes internacionais de câncer cervical, demonstraram a presença do DN A do HPV em mais de $99,7 \%$ dos casos. Atualmente está bem estabelecido que a infecção pelo H PV é o fator central e causal do câncer do colo de útero. ${ }^{6}$

O PAPILOMAVIRUS HUMANO

O svírus do papiloma humano são classificadosnafamília Papillomaviridæe, gênero Papilomavírus. 7,8 São vírus nãoenvelopados, de simetria icosaédrica, com 72 capsômeros e um genoma de D N A de fita dupla circular, constituindo-se de aproximadamente 6.800 a 8.400 pares de bases ${ }^{7,9}$
O genoma do H PV éconstituído por aproximadamente oito open reading frames ( $\mathrm{RF}$ ), possuindo pelo menos seis genes que se expressam precocemente e dois genes que se expressam tardiamente, sendo denominados respectivamente de E (Early) e L (Late) [Figura 1].10.12

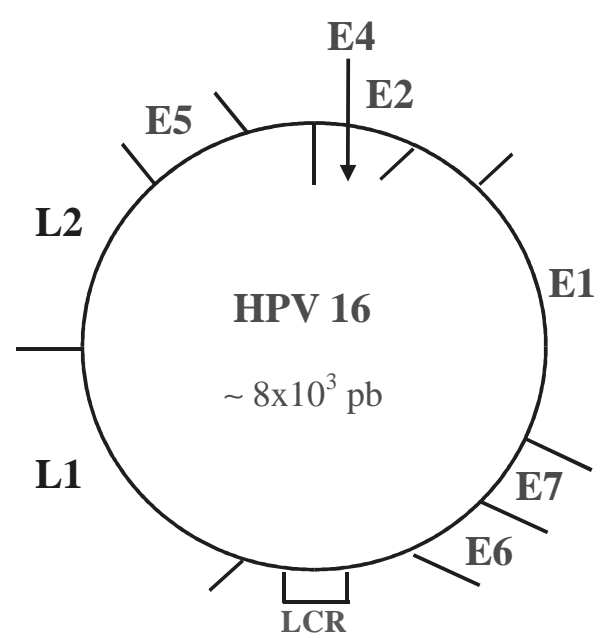

Figura 1 - Genoma do papilomavírus humano 16 (HPV16). $\mathrm{G}$ enoma circular de dupla-fita, mostrando organização e localização dos genes. LCR: Longa Região de Controle.

A região E éformada pelos genes E1, E2, E4, E5, E6 e E7, dentre estes, E1 tem relação com a replicação viral, E2 com a transcrição e replicação, E4 com a maturação viral e alteração da matriz intracelular. E5, E6 e E7 estão envolvidos na transformação celular. ${ }^{10,13-15}$ A região $\mathrm{L}$ é formada pelos genes $L 1$ e $L 2$, que codificam as proteńnas do capsídeo (Q uadro 1). Somando-se a isso, o genoma é dotado de uma região reguladora LCR (Long Control Region) ou URR (U pstream Regulatory Region), variando de 400 a 1000 pbs, localizadas entre as regiões L1 e E6. $N$ essa região, existem seqüências estimuladoras e repressoras da transcrição viral, além da origem de replicação (Q uadro 1).2,13,16

Q uadro 1 - Relação entre os genes de Papilomavírus Humano e suas requeridas funções.

\begin{tabular}{|c|c|c|}
\hline $\begin{array}{l}\text { Expressão } \\
\text { G ênica }\end{array}$ & Genes & Função \\
\hline Precoce & $\begin{array}{l}\text { E1 } \\
\text { E2 } \\
\text { E4 } \\
\text { E5, E6, E7 }\end{array}$ & $\begin{array}{l}\text { Replicação do DNA viral } \\
\text { Controle da transcrição e replicação } \\
\text { Maturação do vírus e alteração da matriz intracelular } \\
\text { Estímulo da proliferação e transformação celular }\end{array}$ \\
\hline Tardia & $\begin{array}{l}\mathrm{L} 1 \\
\mathrm{~L} 2\end{array}$ & $\begin{array}{l}\text { Codifica proteína principal do capsídeo } \\
\text { Codifica proteína secundária do capsídeo }\end{array}$ \\
\hline
\end{tabular}


Novos Tipos

O s H PV são um grupo heterogêneo de vírus. As análises de seqüências de D N A têm permitido identificar mais de 100 tipos virais. ${ }^{5}$ Atualmente considera-se um novo tipo de H PV quando as seqüências de nucleotídeos dos genes L1, E6 e E7 (aproximadamente $30 \%$ do genoma viral) diferir em mais de $10 \%$ dos tipos conhecidos. Se esse percentual for menor que $2 \%$, então, o novo vírus isolado é designado como uma variante do mesmo tipo. 0 s subtipos virais correspondem a genomas cuja seqüência nucleotídica nessas regiões gênicas diferir entre $2 \%$ e $10 \%$ dos tipos já descritos. ${ }^{13,17}$
Manutenção Viral

O s HPV infectam tanto as mucosas quanto os tecidos cutâneos. Assim, podem ser classificados segundo seu tropismo como cutaneotrópicos e mucosotrópicos. ${ }^{2,16-18}$ As diferenças em se tratando de tropismo ainda carecem de estudos, porém, nos últimos anos, tem-se estudado intensamente sobre as variações discretas em certas porções do genoma que possam resultar em potencial patogênico distinto. ${ }^{19,20} \mathrm{~A}$ diferença entreostipos deH PV encontrados em tumores benignos e malignos permite classificá-los como H PVs de baixo e alto risco oncogênico (Q uadro 2). 2,16,21

Quadro 2 - Relação entre o tipo de HPV e a doença associada.

\begin{tabular}{|c|c|c|}
\hline Tropismo & Doença & Tipo de HPV ${ }^{i}$ \\
\hline $\begin{array}{c}\text { Cutaneotrópico } \\
\text { (Baixo Risco) }\end{array}$ & $\begin{array}{l}\text { Verrugas plantares } \\
\text { Verrugas comuns } \\
\text { Verrugas vulgares(planas) } \\
\text { Outras lesões cutâneas (exs.: cistos } \\
\text { epidérmicos, carcinoma da laringe) } \\
\text { Epidermodisplasia verruciformis } \\
\text { Papilomatose respiratória recorrente } \\
\text { Papilomas/Carcinomas conjuntivos } \\
\text { Condiloma acuminado (verrugas } \\
\text { genitais) }\end{array}$ & $\begin{array}{l}1,2,4,63 \\
2,1,7,4,26,27,29,41,57,65,77 \\
1,3,4,10,28 \\
3,10,26,27,28,38,41,49,75,76 \\
6,11,16,30,33,36,37,38,41,48 \\
60,72,73 \\
2,3,10,5,8,9,12,14,15,17,19 \\
20,21,22,23,24,25,36,37,38 \\
47,50 \\
6,11 \\
6,11,16 \\
6,11,30,42,43,45,51,54,55,70\end{array}$ \\
\hline $\begin{array}{c}\text { Mucosotrópico } \\
\text { (Alto risco) }\end{array}$ & $\begin{array}{l}\text { Neoplasia Intraepitelial Cervical (NIC) } \\
\text { x Não específico } \\
\text { x Baixo risco (NIC I) } \\
\text { x Alto risco (NIC II) } \\
\text { Carcinoma cervical }\end{array}$ & $\begin{array}{l}30,34,39,40,53,57,59,61,62, \\
64,66,67,68,69 \\
6,11,16,18,31,33,35,42,43,44, \\
45,51,52,74 \\
16,18,6,11,31,34,33,35,39,42, \\
44,45,51,52,56,58,66 \\
16,18,31,45,33,35,39,51,52, \\
56,58,66,68,70\end{array}$ \\
\hline
\end{tabular}

A ordem indica a freqüência relativa; negrito indica a associação mais freqüente. ${ }^{13}$ 
0 receptor para entrada do H PV nas células epiteliais não foi ainda funcionalmente identificado. $\mathrm{N} o$ entanto uma proteína denominada integrina $\alpha$-seis $\beta$-quatro tem sido sugerida como uma forte candidata a receptor para HPV. Geralmente as integrinas se expressam primariamente durante a cicatrização. Existe uma crescente aceitação de que os proteoglicanos (heparan sulfato) atuam como receptores primários do H PV, mediando a anexação viral. Esses proteoglicanos interagem com a porção caboxi-terminal da proteína L1 do H PV. Apesar de serem largamente distribuídas na superfície de muitas células, elas podem não ser suficientes para permitir uma entrada eficiente do vírus. ${ }^{13,19,22,23}$

O ciclo de vida produtivo dos H PV é dependente da diferenciação celular. ${ }^{2,16,24}$ A infecção inicial por H PV ocorre nas steam cells, localizadas nas camadas mais baixas do epitélio estratificado. As células da camada basal se dividem e, posteriormente, são conduzidas a um processo de diferenciação gerando células epiteliais maduras. As células de divisão transitória produzem células filhas que migram da camada basal, direcionando-se às camadas mais externas, diferenciando-se ao longo do trajeto. ${ }^{19}$

Após a entrada do H PV na célula, o genoma viral se estabiliza na forma de elementos extracromossômicos no núcleo e o número de cópias virais aumenta para aproximadamente 50 por célula. Ao se dividirem, essas células infectadas distribuem eqüitativamente o DN A viral entre as células filhas. U ma das células filhas migra da camada basal e inicia o programa de diferenciação celular. As demais células filhas continuam dividindo-se na camada basal e servem de reservatório de D N A viral para as posteriores divisões celulares. Sendo a produção do H PV restrita às células suprabasais, as células na camada basal não são lisadas pela produção de novos vírus, continuando a proliferação. ${ }^{10,19,24}$

\section{Expressão do Genoma do HPV}

As diferenças genômicas, entre os HPVs de alto e baixo risco oncogênicos, acabam por auxiliar no entendimento das ações virais junto ao genoma da célula hospedeira e até justificam as diferenças na capacidade tranfformante destes agentes. De forma contrastante, a presença do genoma viral extracromossomal (epissomal) nos tumores benignos ou normalmente a forma linear (integrada) nos tumores malignos acaba por determinar um comportamento viral mais agressivo nas regiões infectadas de H PV. ${ }^{1,25-27}$

A integração do genoma viral parece ocorrer ao acaso. Se, por um lado, não há sítio preferencial de integração no genoma, por outro, há uma grande especificidade no local de clivagem do DN A circular do vírus, como no caso dos tumores malignos, onde a integração do DNA viral ocorre devido à clivagem na região dos genes $E 1 / E 2$, com conseqüente interrupção do controle transcricional exercido pelo gene E2. 20,28

$O$ s genomas virais com mutações em E 1 ( $O$ pen Read Frame - ORF) induzem à perda da capacidade de manutenção do estado epissomal do H PV, devido a uma deficiência na replicação viral bem como na transcrição de genes de expressão tardia. ${ }^{24}$

Após a infecção viral, os primeiros genes a se expressarem são os genes E 1 e E2 cujos produtos estão envolvidos na replicação do genoma viral. E1 eE2 agem independentes quanto aos sítios de ligações na origem de replicação (URR) do papilomavírus. Porém, poderá ocorrer a interação das proteínas E1-E2 formando um complexo multimérico queauxilia na replicação viral. ${ }^{19,20}$ 0 produto do gene E1, uma fosfoproteína nuclear de $68 \mathrm{kD}$ a com atividade AT Pase e D N A helicase, liga-se na origem de replicação do D N A viral sendo essencial para a replicação do papilomavírus. ${ }^{29}$

A proteína codificada pelo gene E2 é um fator que regula a transcrição dos oncogenes E6 e E7.1,10,15 A proteína E2 é composta de três domínios funcionais denominados de A, B e C. $O$ domínio A é dividido em A1 e A2, que se organizam em alfa hélice, estando localizados próximos à região $\mathrm{N}$-terminal da molécula, apresentam atividade voltada para a ativação transcricional de alguns genes. 0 domínio $C$ está localizado na região C-terminal. Essa região possibilita a interação de E2 com o DNA, bem como facilita a dimerização da proteína E2. $O$ domínio $B$ auxilia na estruturação da proteína E2, por interligar as regiões $A$ e $C .{ }^{30}$

A proteína de E2 se une ao DNA em forma de dímeros especificamente na seqüência 5 '-ACCG N N N N -CG GT-3' que, por sua vez, poderá encontrarse repetida várias vezes na região controladora do papilomavírus. Além de atuar como um forte fator transcricional, recentemente, demonstrou-se que a transcrição, a partir dos promotores da região E6 dos H PV 16 e 18, é fortemente reprimida por essa proteína em células SW 13 ou em queratinócitos humanos. ${ }^{25-27}$

Contudo, essa aparente discrepância na ação da proteína E2 no genoma viral é explicada pela distância encontrada entre as regiões de interação de E2 e o sítio promotor dos genes E6 e E7. Q uando o sítio de união de E2 está a mais de 100 pares de base (pb) do sítio +1 (onde se inicia a transcrição), existirá a ativação das regiões promotoras dos genes E6 e E7. Porém, quando a distância for menor, ocorrerá a repressão da ativação dos promotores (TATA) detranscrição. A repressão devese à interação da proteína E2 próxima aos sítios de transcrição aos quais os fatores estimuladores da transcrição se ligariam. Assim, esse impedimento espacial inibe a expressão de genes atuantes na imortalização celular como é o caso de E6 e E 7.25-27 
A proteína $\mathrm{E} 6$ de $\mathrm{H} \mathrm{PV}$ de alto risco oncogênico associa-se à proteína $\mathrm{p53}$, que regula a passagem pelas fases $\mathrm{G} 1 / \mathrm{S}$ e $\mathrm{G} 2 / \mathrm{M}$. E6 recruta as proteínas celulares, como é 0 caso das proteínas da família AP1 (E6-AP) que funcionam como uma ubiquitina ligase; atuando no complexo p53, podendo impedir o efeito supressor da proteína no ciclo celular. A formação desse complexo protéico resulta na ubiquitinação de p53 seguido por sua rápida degradação mediada por um complexo proteossômico. E6, além de reprimir a ação de p53, também tem como função a atividade de telomerase, podendo associar com proteínas ligantes do cálcio ERC 55, fatores de resposta do Interferon, IRF3, ou, até mesmo, associar a proteínas de integração viral. 2,5,11,19,24

A função principal do geneE 7 dos H PV dealto risco é desregular a maquinaria do ciclo celular da célula infectada principalmente pela indução da transição da fase $\mathrm{Go} / \mathrm{S}$. Isso é efetuado através da ativação de vários genes celulares pela E7 e pela interação dessa proteína com as proteínas que regulam o ciclo celular. ${ }^{2}$ A proteína E 7 dos H PV de alto risco oncogênico liga-se às proteínas da família $\mathrm{pR} b$. Essa interação permite que E2F atue na ativação constitutiva dos fatores transcricionais, o que levaria à progressão do ciclo celular. E 7 também forma complexos com ciclinas A e $\mathrm{E}$, bem como provoca inativação de p21 e p27. ${ }^{11}$

$O$ s genes $E 6$ e $E 7$ são considerados os genes de maior poder de transformação do papilomavírus humano. Três tipos de evidências demonstram a importância do papel desses genes na manutenção do fenótipo de células alteradas: 1) esses genes possuem potencial de transformação in vitro; 2) células infectadas com esses genes podem induzir à formação de tumores em ratos; 3) a inibição da expressão desses genes leva à reversão do fenótipo transformado.2 Acredita-se que a expressão das proteínas E6 e E7 seja responsável pelo início e a manutenção do processo que culmina no câncer cervical. ${ }^{31}$

\section{CO NCLUSÃO}

Com 0 avanço da tecnologia e 0 advento de novas técnicas moleculares, a detecção de H PV tornou-se cada vez mais precisa, o que nos permite correlacionar 0 vírus ao desenvolvimento de alguns tipos de câncer. $D$ entre as técnicas mais recentes, destaca-se a PCR, por ser um método de extrema eficácia, favorecendo uma detecção mais sensível e específica para os diversos tipos de H PV.

Pode-se considerar o H PV como mais um fator relacionado à formação de neoplasias entre os diversos fatores causais do câncer como álcool, cigarro e radiação ultravioleta. Suas proteínas virais E6 e E7 são produtos de oncogenes capazes de interagir com as proteínas controladoras do ciclo celular. Em decorrência dessa interação a célula é conduzida à transformação, imortalização celular e, posteriormente, ao câncer.

A transmissão do H PV para o trato genital, preferencialmente, ocorre através do contato sexual. Sendo assim, é de extrema importância educar a população quanto ao modo de transmissão, a fim de se evitar a disseminação generalizada do vírus. Para isso, é necessário enfatizar os métodos preventivos bem como os comportamentos de risco.

A educação visa tanto à prevenção quanto à detecção precoce de uma doença. Até o presente momento, as mulheres com tumores do colo de útero são a parcela da população mais atingida pelo H PV de alto risco oncogênico. Sendo assim, é importante realizar campanhas que as conscientizem da necessidade de realizarem exames ginecológicos preventivos. A detecção precoce da lesão causada do H PV acaba permitindo a utilização de abordagens terapêuticas menos invasivas, ao contrário do que ocorre quando são detectados tumores de grau mais avançado. Vale ressaltar que os homens desempenham o papel de transmissores do vírus para as mulheres e, dessa forma, também devem ser alvos da educação preventiva.

\section{AG RADECIMENTOS}

Agradecemos às professoras $\mathrm{M}$ egmar Aparecida dos Santos Carneiro (IPT SP) e Silvia H elena Rabelo dos Santos (Faculdade de Farmácia) da Universidade Federal deG oiás, pelo apoio prestado na confecção deste trabal ho.

\section{REFERÊN CIAS}

1. Jacob SE, Sreevidya S, Chacko E, Pillai M R. Cellular manifestations of human papillomavirus infection in laryngeal tissues. J Surg O ncol. 2002;79:142-50.

2. Kisseljov FL. V irus-associated human tumors: cervical carcinomas and papilloma viruses. Biochemistry. 2000;65(1):68-77. Translated from Biokhimiya. 2000;65(1):79-91.

3. Santos O SN , Romanos VTM , Wigg D M . Introdução à virologia humana. Rio deJaneiro: GuanabaraKoogan; 2002.

4. Lindel K, Beer KT, Laissue J, G reiner RH, Aebersold D M . $H$ uman papillomavirus positive squamouscell carcinoma of the oropharynx: a radiosensitive subgroup of head and neck carcinoma. C ancer. 2001:92(4);805-13.

5. Scully C. O ral squamouscell carcinoma: from an hypothesis about a virus, to concern about possiblesexual transmission. O ral 0 ncol. 2002;38:227-34.

6. Franco EL, D uarte-Franco E, Ferenczy A. C ervical cancer: epidemiology, prevention and the role of human papillomavirus infection. Can Med Assoc J. 2001;164(7):1017-25. 
7. NevesD, C amaraGN L, AlencarTR, daCruz M R, M artins CRF, C arvalho LGS. Prevalence of human papillomavirus in penilecarcinoma. BrazJ U rol. 2002;28(3):221-6.

8. Rivoire AW, Capp E, Carleta EH, Silva BSI. Bases biomoleculares da oncôgenesecervical. Rev $\mathrm{Bras} C$ ancerol. 2001:47(2);179-84.

9. N elson LM , Rose RC, M oroianu J. N uclear importstrategies of high risk H PV 16 L1 major capsid protein.J Biol Chem. 2002:277(26);23958-64.

10. Fehrmann F, Laimins LA. Human papillomaviruses: targeting differentiating epithelial cells for malignant transformation. O ncogene. 2003;22:5201-7.

11. Zur H ausen H . Papillomaviruses causing cancer: evasion from host-cell control in early events in carcinogenesis. J $\mathrm{N}$ atl C ancer Inst. 2000;92(9):690-8.

12. Rosenstierne $M W, V$ inther $J, H$ ansen $C N$, Prydsoe $M$, $\mathrm{N}$ orrild $\mathrm{B}$. I dentification and characterization of a cluster of transcription start siteslocated in theE $60 \mathrm{RF}$ of human papillomavirustype 16.J G en Virol. 2003;84:2909-20.

13. Burd EM . H uman papillomavirusand cervical cancer. C lin M icrobiol Rev. 2003;16(1):1-17.

14. Lin BY, M akhov AM, Griffith JD, BrokerT R, Chow LT. Chaperone proteins abrogate inhibition of the human papillomavirus (H PV) E1 replicative helicase by theH PV E2 protein. M ol C ell Biol. 2002;22(18):6592-604.

15. Lee D, Lee B, Kim J, Kim DW, Choe J. CAM P response element-binding protein-binding protein binds to human papillomavirus E2 protein and activates E2 dependent transcription. J Biol Chem. 2000;275(10):7045-51.

16. Silva AM TC, Amaral M VT, da Cruz AD. 0 papel do papiloma vírus humano no câncer. Biotecnol Ciênc D esenvol. 2003;29:48-54.

17. Berkhout RJ M , Bavink JN B, ter Schegget J. Persistence of human papillomavirusD N A in benign and (pre)malignant skin lesionsfrom renal transplant recipients. J Clin M icrobiol. 2000;38(6):2087-96.

18. Crish JF, BoneF, Balasubramanian S, Zaim TM , WagnerT, Yun J, et al. Suprabasal of the human papillomavirustype 16 oncoproteins in mouse epidermis alters expression of cell cycle regulatory proteins. Carcinogenesis. 2000;21(5):1031-7.

19. Stubenrauch F, LaiminsLA. H uman Papillomaviruslifecycle: activeand latent phases. C ancer Biol. 1999;9:379-86.
20. Villa LL. Aspectos moleculares da oncogênese por papilomavirus. In: Bibbo M, Silva Filho AM. Lesões relacionadas à infecção por $\mathrm{H}$ PV no trato anogenital. Rio deJ aneiro: Revinter; 1998. p. 51-8.

21. Cavalcanti SM B, Zardo LG, PassosM RL, O liveira LH S. Epidemiological aspects of human papillomavirusinfection and cervical cancer in Brazil. J Infect. 2000;20:80-7.

22. Bousarghin L, Touzé $A$, Sizaret PY, C oursaget P. H uman papillomavirus types 16,31 , and 58 use different endocytosis pathways to enter cells. J Virol. 2003;77(6):3846-50.

23. Giroglou T, Florin L, Schafer F, Streeck RE, Sapp M . H uman papillomavirusinfection requirescell surface heparan sulfate. J Virol. 2001;75(3):1565-70.

24. ThomasT J, H ubertWG, Ruesch M N , LaiminsLA. H uman papillomavirus type 31 oncoproteins E6 and E7 are required for the maintenance of episomesduring the viral life cycle in normal human keratinocytes. Proc $\mathrm{N}$ atl Acad Sci. 1999;96:8449-54.

25. Bibbo M , Silva Filho AM . Lesões relacionadasà infecção por H PV no trato anogenital. Rio de Janeiro: Revinter; 1998.

26. Alvarez IA, Lazo PS, G onzales SR, Tapia PR, BatallaFN , $\mathrm{N}$ ieto CS. U sing polymerase chain reaction to human papillomavirus in oral and pharyngolaryngeal carcinomas. Am J 0 tolaryngol. 1997;18(6):375-81.

27. García-C arrancáA, G ariglio P. Aspectos moleculares de los papillomavirushumanosy su relación com el câncer cervicouterino. Rev Invest Clín. 1993;45:85-92.

28. Bosch FX, Rohan T, Schneider A, Frazer I, Pfister H, $C$ astellsagué $X$, et al. Papillomavirus research update: highlights of the Barcelona H PV 2000 international papillomavirus conference. J C lin Pathol. 2001;54:163-75.

29. Benson JD, H owley P. Amino-terminal domains of the bovinepapillomavirustipe $1 \mathrm{E} 1$ and $\mathrm{E} 2$ proteinsparticipate in complex formation. J Virol. 1995;69(7):4364-72.

30. Lai M C, Teh BH , Tarn WY. A human papillomavirusE2 transcriptional activator. J Biol Chem. 1999;274(17):11832-41.

31. Bechtold V, Beard P, Raj K. H uman papillomavirus type $16 \mathrm{E} 2$ protein hasno effect on transcription from episomal viral D N A. J V irol. 2003;77(3):2021-8. 